\title{
Acute biliary pancreatitis in cholecystectomised patients
}

\author{
Fatih Ciftci, ${ }^{1}$ Turgut Anuk ${ }^{2}$ \\ ${ }^{1}$ Department of General Surgery, Vocational School of Health Services, Istanbul Gelisim University, Istanbul, Turkey \\ 2Department of General Surgery, Kafkas University Faculty of Medicine, Kars, Turkey
}

\begin{abstract}
OBJECTIVE: The present study is an evaluation of cases of acute biliary pancreatitis that developed subsequent to cholecystectomy.

METHODS: Total of 44 patients were assessed in this retrospective study. Demographic characteristics, severity of illness, time elapsed between cholecystectomy and development of pancreatitis, whether endoscopic sphincterotomy (ES) was performed, surgical procedure used, duration of hospitalization, and mortality data were recorded.

RESULTS: Mean age of all patients was $60.14 \pm 16.4$ years (range: $20-85$ years), and female:male ratio was 28:16. Mean length of time elapsed between cholecystectomy and development of acute pancreatitis was 80.6 months (range: 5-230 months). Gallstones and biliary sand were found in the choledochi of 36 patients upon endoscopic retrograde cholangiopancreatography (ERCP), but not observed in the remaining 8 patients. ES was performed and material was extracted in 32 of the 36 patients, but stone extraction was unsuccessful in 4 cases; 3 patients underwent open surgery with choledochus exploration and 1 patient died. Excluding this patient, mean duration of hospitalization was $7.5 \pm 2.5$ days.
\end{abstract}

CONCLUSION: Stones in bile ducts may remain asymptomatic for long periods after cholecystectomy. However, some stones trigger acute pancreatitis months or years after cholecystectomy, causing risk of mortality. ERCP and ES are the standard treatments. If these are unsuccessful, the choledochus may be explored via open or laparoscopic surgery.

Keywords: Acute biliary pancreatitis; cholecystectomy; endoscopic retrograde cholangiopancreatography; endoscopic sphincterotomy.

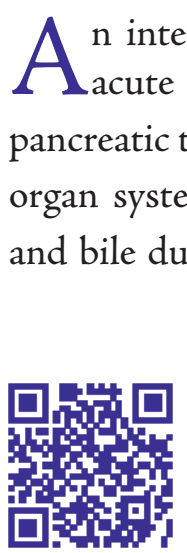

A international consensus conference defined acute pancreatitis (AP) as inflammation of pancreatic tissue affecting both adjacent and distant organ systems to varying degrees [1]. Gallbladder and bile duct stones cause $35 \%$ to $65 \%$ of all cases 34306 Avcilar, Istanbul, Turkey.

Tel: +90 212 - 4227000 e-mail: oprdrfatihciftci@gmail.com of AP $[2,3]$. Prevalence of stones in the choledochus of cholecystectomized patients is $2 \%$ to $15 \%$ $[4,5]$. Incidence of acute biliary pancreatitis (ABP) has been well studied. In the present study, ABP patients who had previously undergone cholecystec-

Received: September 10, 2016 Accepted: February 10, 2017 Online: May 10, 2017

Correspondence: Dr. Fatih CIFTCI. Istanbul Gelisim Universitesi, Saglik Hizmetleri Meslek Yuksekokulu,

(c) Copyright 2017 by Istanbul Northern Anatolian Association of Public Hospitals-Available online at www.kuzeyklinikleri.com 
tomy were evaluated and our clinical experience is described.

\section{MATERIALS AND METHODS}

Data of 44 patients with history of cholecystectomy who were diagnosed with ABP between September 2001 and December 2014 were retrospectively evaluated. Most of the patients had undergone cholecystectomy at our clinic; 4 had surgery in another clinic. During this time period, total of 4744 cholecystectomies were performed due to symptomatic cholelithiasis in our general surgery department. No choledocholithiasis or acute pancreatitis was detected at time of surgery. There was no history of biliary intervention prior to surgery. Four patients who had surgery at another clinic also had no history of intervention or pancreatitis. Among these 4744 patients, 3 cases with bile duct injury were managed via primary repair and T-tube placement. AP presentation included specific abdominal pain with increase in serum amylase level 3 times greater than reference range [6]. Ranson criteria were used to describe severity of illness; score below 3 reflects mild illness, while higher scores indicate severe disease [7]. Demographic characteristics, severity of illness, time elapsed between cholecystectomy and development of pancreatitis, whether endoscopic sphincterotomy (ES) was performed, surgical procedure used, duration of hospitalization, and mortality data were recorded. Etiological cause was determined by evaluating anamnesis, physical findings, and laboratory test results. ABP was diagnosed when AP was associated with laboratory findings of cholecystitis and concomitant radiological evidence of stones in the bile ducts [2]. Patients with extrabiliary causes of cholestatic jaundice and those who did not undergo cholecystectomy were excluded. Patients who developed AP within 3 months of cholecystectomy were also excluded due to possibility that AP was caused by stones overlooked during cholecystectomy [2].

\section{Statistical analysis}

SPSS for Windows, Version 15.0 software (SPSS Inc., Chicago, IL, USA) was used to analyze de-
TABLE 1. Demographic features

Age (years)

$60.14 \pm 16.4$

Gender (female/male)

(range: 20-85)

Time to development of

$28 / 16$

pancreatitis after cholecystitis (days)

$E R C P+E S, n(\%)$

$80.6(5-230)$

Laparotomy + exploration

$36(81.8)$

$3(6.8)$

of the choledochus, n (\%)

Mortality

Hospitalization duration (days)*

$7.5 \pm 2.5$

Mean amylase level (units/L)

$749 \pm 387$

Mean choledochal diameter $(\mathrm{mm})$

$14.29 \pm 3.89$

ERCP: Endoscopic retrograde cholangiopancreatography; ES: Endoscopic sphincterotomy. Mean \pm SD. *Excluding the patient who died.

scriptive statistics. Continuous variables are presented as mean $\pm \mathrm{SD}$ and categorical variables as percentages and numbers.

\section{RESULTS}

Mean patient age (44 patients) was $60.14 \pm 16.4$ years (range: $20-85$ years), and female:ratio was 28: 16. Based on Ranson criteria, 36 patients had mild AP and 8 cases were severe. Demographic characteristics, time elapsed between cholecystectomy and pancreatitis, duration of hospitalization, mortality rate, and treatment methods are provided in Table 1. Mean time elapsed from cholecystectomy to AP development was 80.6 months (range: 5-230 months). Mean amylase level was $749 \pm 387$ $\mathrm{U} / \mathrm{L}$ and mean choledochal diameter $14.29 \pm 3.89$ $\mathrm{mm}$. Stones and sand were found in the bile ducts of 24 patients using magnetic resonance cholangiopancreatography and/or in 20 on ultrasonography image. ERCP was performed in all patients. ES and stone extraction were successful in 32 of the 36 patients in whom the choledochus contained stones and sand. Two patients had impacted stones in the distal choledochus, and ERCP was unsuccessful. ES could not be performed in 2 other patients with large ( $>2 \mathrm{~cm}$ in diameter) stones in the choledochus and duodenal diverticula close to the papilla. Stones 
were not found in the remaining 8 patients, but their choledochi were wider than normal on ERCP.

In 4 patients with no indications of periampullar tumor on ERCP or radiologically, it was thought stones might have fallen into the intestinal lumen and ES was performed. Laparotomy with insertion of T-tube was performed to explore the choledochus and clean the bile duct in 7 patients with stones that were not extracted during ERCP. One patient with impacted stones developed necrotizing pancreatitis. Necrosectomy with concomitant choledochal exploration, bile duct cleansing, and Ttube insertion was performed; however, the patient died from multiple organ failure associated with sepsis on day 48 of hospitalization after completion of scheduled re-laparotomy and peritoneal lavage. Excluding this patient, mean duration of hospitalization was $7.5 \pm 2.5$ days.

\section{DISCUSSION}

Data on prevalence and severity of $\mathrm{ABP}$ in patients who have undergone cholecystectomy are limited. In published studies, $2 \%$ to $15 \%$ of patients had bile duct stones after open and laparoscopic cholecystectomies $[4,5,8,9]$. Some stones remain asymptomatic, but others trigger potentially fatal AP months, or even years, after cholecystectomy. One study found that rate of symptomatic choledochus stones was $2.5 \%$ [4]. Another study of $278 \mathrm{AP}$ patients found that $10 \%$ developed $\mathrm{ABP}$ subsequent to cholecystectomy; illness tended to be severe, and the patients required referral to tertiary medical care center [2]. The cited authors reported mean of 4 years between cholecystectomy and ABP [2]. In the present study, mean elapsed time was 80.6 months (range: 5-230 months). An earlier study at another clinic followed annual average of 100 AP cases [10]. In the 13-year period of the current study, 44 cases of postcholecystectomy $\mathrm{ABP}$ constituted $2 \%$ of all AP cases. ERCP and ES are standard approaches used for treatment of patients with choledochal stones subsequent to cholecystectomy. However, some authors have reported that these techniques are unsuccessful approximately $10 \%$ of the time $[4,10-13]$.
When ERCP and ES fail, laparoscopic or open surgery and choledochal exploration is the approach of choice $[4,11]$. In our study, ERCP and ES were unsuccessful in $9.1 \%$ of cases. This rate is similar to that of previous reports. These patients underwent open surgery with choledochus exploration and T-tube insertion. Duodenal diverticula have been reported to be significant trigger of recurrent $\mathrm{ABP}$ subsequent to cholecystectomy. One study found that 15-year frequency of bile disease in cases with duodenal diverticula was $10.2 \%$ [14]. Gloor et al. reported ABP recurrence frequency of $8 \%$ in postcholecystectomy patients with duodenal diverticula [2]. In our series, prevalence of such diverticula was $4.5 \%$. A previous study found that $\mathrm{ABP}$ was more frequent after cholecystectomy in patients with choledochal diameter greater than $10 \mathrm{~mm}$ [15-19]. In our series, choledochal diameter of all patients was greater than normal. Presentation of ABP following cholecystectomy ranges from mild edematous pancreatitis to clinically severe necrotizing pancreatitis; rate of severe disease was reported to be $61.5 \%[2,20,21]$. In one study, rate of pancreatic necrosis among those with severe pancreatitis was $50 \%$ and mortality was $8 \%$. Severe pancreatitis was evident in 4 patients $(9.1 \%)$ in our study. One patient developed pancreatic necrosis (25\%) and ultimately died of sepsis and multiple organ failure.

In conclusion, stones in the bile ducts should be considered possible cause of AP developing after cholecystectomy. Although some stones remain asymptomatic for a long period after cholecystectomy, others may predispose patients to potentially fatal AP. In such cases, ERCP and ES are standard treatment approaches. If these techniques are unsuccessful, laparoscopic or open surgery with choledochus exploration may be subsequent alternative.

Conflict of Interest: None declared.

Financial Disclosure: The authors declared that this study has received no financial support.

Authorship contributions: Concept - F.C.; Design - F.C.; Supervision - F.C.; Materials; F.C., T.A.; Data collection/or processing - F.A., T.A.; Analysis and/or interpretation - F.C., T.A.; Literature search - F.C.; Writing - F.C.; Critical review - F.C. 


\section{REFERENCES}

1. Bradley EL 3rd. A clinically based classification system for acute pancreatitis. Summary of the International Symposium on Acute Pancreatitis, Atlanta, Ga, September 11 through 13, 1992. Arch Surg 1993;128:586-90.

2. Gloor B, Stahel PF, Müller CA, Worni M, Büchler MW, Uhl W. Incidence and management of biliary pancreatitis in cholecystectomized patients. Results of a 7-year study. J Gastrointest Surg 2003;7:372-7.

3. Gül M, Aliosmanoğlu, Türkoğlu A, Uçmak F, Ülger BV, Oğuz A, et al. Kolesistektomili hastalarda akut biliyer pankreatit. 2012; $28: 186-8$

4. Alexakis N, Lombard M, Raraty M, Ghaneh P, Smart HL, Gilmore I, et al. When is pancreatitis considered to be of biliary origin and what are the implications for management? Pancreatology 2007;7:131-41.

5. Cox MR, Budge JP, Eslick GD. Timing and nature of presentation of unsuspected retained common bile duct stones after laparoscopic cholecystectomy: a retrospective study. Surg Endosc 2015;29:2033-8.

6. Potter MW, Shah SA, McEnaney P, Chari RS, Callery MP. A critical appraisal of laparoscopic staging in hepatobiliary and pancreatic malignancy. Surg Oncol 2000;9:103-10.

7. Toouli J, Brooke-Smith M, Bassi C, Carr-Locke D, Telford J, Freeny $\mathrm{P}$, et al. Guidelines for the management of acute pancreatitis. J Gastroenterol Hepatol 2002;17 Suppl:S15-39.

8. Yanar F, Alıs H. Akut pankreatitlerin prognozunun belirlenmesinde skorlama sistemlerinin rolü. Turkiye Klinikleri J Gen Surg-Special Topics 2011;4: 43-7.

9. Rogers AL, Farha GJ, Beamer RL, Chang FC. Incidence and associated mortality of retained common bile duct stones. Am J Surg 1985;150:690-3.

10. Braghetto I, Debandi A, Korn O, Bastias J. Long-term follow-up after laparoscopic cholecystectomy without routine intraoperative cholangiography. Surg Laparosc Endosc 1998;8:349-52.
11. Anwar S, Rahim R, Agwunobi A, Bancewicz J. The role of ERCP in management of retained bile duct stones after laparoscopic cholecystectomy. N Z Med J 2004;117:U1102.

12. Chiappetta Porras LT, Nápoli ED, Canullán CM, Quesada BM, Petracchi JE, Oría AS. Laparoscopic bile duct reexploration for retained duct stones. J Gastrointest Surg 2008;12:1518-20.

13. Leese T, Neoptolemos JP, Carr-Locke DL. Successes, failures, early complications and their management following endoscopic sphincterotomy: results in 394 consecutive patients from a single centre. Br J Surg 1985;72:215-9.

14. Williams EJ, Green J, Beckingham I, Parks R, Martin D, Lombard M; British Society of Gastroenterology. Guidelines on the management of common bile duct stones (CBDS). Gut 2008;57:1004-21.

15. Mackenzie ME, Davies WT, Farnell MB, Weaver AL, Ilstrup DM. Risk of recurrent biliary tract disease after cholecystectomy in patients with duodenal diverticula. Arch Surg 1996;131:1083-5.

16. Grönroos JM, Haapamäki MM, Gullichsen R. Effect of the diameter of the common bile duct on the incidence of bile duct stones in patients with recurrent attacks of right epigastric pain after cholecystectomy. Eur J Surg 2001;167:767-9.

17. Billi P, Barakat B, D'Imperio N, Pezzilli R. Relapses of biliary acute pancreatitis in patients with previous attack of biliary pancreatitis and gallbladder in situ. Dig Liver Dis 2003;35:653-5.

18. Scheurer U. Acute pancreatitis--ERCP/endoscopic papillotomy (EPT) yes or no? Swiss Surg 2000;6:246-8.

19. Peterlejtner T, Szewczyk T, Firkowski P, Zdrojewski M. Endoscopic treatment of the choledocholithiasis--effectiveness, safety and limitations of the method. Pol Przegl Chir 2012;84:333-40.

20. Kohut M, Nowak A, Nowakowska-Duiawa E, Marek T. Presence and density of common bile duct microlithiasis in acute biliary pancreatitis. World J Gastroenterol 2002;8:558-61.

21. Singh VK, Moran RA, Afghani E, de-Madaria E. Treating acute pancreatitis: what's new? Expert Rev Gastroenterol Hepatol 2015;9:901-11. 